Journal of the Scholarship of Teaching and Learning, Vol. 21, No. 4, December 2021, pp. 5-10. doi: 10.14434/josotl.v21i4.33792

\title{
Education, Politics, and the Crisis of Democracy in the Age of Pandemics
}

\author{
Henry A. Giroux \\ McMaster University
}

In the age of the pandemic, higher education is increasingly defined by modes of governance modeled after a business culture. As the pandemic continues to ravage countries across the globe, education has accelerated its emphasis on job training, online tools, and remote learning, while further aligning curricula with business interests (Alford and Kroll, 2020). With the move to online teaching, instrumental rationality and the language of technique have increasingly become the lingua franca of education. Remote teaching has moved to the forefront of discussions about pedagogy and in doing so has generated a preoccupation with methods and training skills, which not only displace serious concerns about the role of higher education as a public good but also placing unacceptable burdens on both teachers and students (School Magazine Editorial Action Toronto, 2021).

Questions about improving delivery, tutorials, recorded lectures, contract grading, and how to give students bonus marks for uploading their notes have moved to the forefront of pedagogical consideration. Matters concerning regulating screen time replace crucial pedagogical issues about fostering deep engagement and critical thinking among students about crucial social issues. What disappears in diverse forms of pandemic pedagogy is what Pope Francis describes as the need for students to be attentive "to grave social injustices, violations of rights, terrible forms of poverty, and the waste of human lives. Moreover, he has advocated that educators "leave behind superficial approaches to education and the many short-cuts associated with utility, (standardized) test results, functionality and bureaucracy, which confuse education with instruction and end up atomizing our cultures" (Cummings McLean, 2020).

In this instance, there is a call for pedagogical approaches that are transformative, empowering, and deeply examine what role education should play in furthering a democracy in a time of growing tyranny. Unfortunately, pandemic pedagogy is neither on the side of expanding civic culture, social justice, or democracy. For instance, teaching and learning centers in many universities now dominate educational issues, largely concerned with providing training sessions on how to use a variety of teaching methods and platforms that extend from teaching Zoom classes to exploring the diverse vagaries of videoconferencing (Blum, 2020).

As higher education succumbs to a business culture and cult of efficiency, it removes itself from issues regarding the complex relationships among knowledge, power, and the acquisition of agency. Matters of purpose and meaning become fetishized within a discourse of hyper instrumental reason that serves to hermetically situate faculty and students within a fetishized discourse of efficiency. What is lost here is the pedagogical imperative of teaching students to be thoughtful, informed, and engaged critical citizens. There is little talk about how education should be a place where students realize themselves as citizens or, for that matter, the role of faculty as public intellectuals who connect their work to crucial social problems while addressing pedagogy as a moral and political project.

The COVID-19 pandemic has further intensified the corporatization of the neoliberal university. This is evident in the increasing control of universities by managerial elites, the loss of power by faculty in shaping governance and the mission of higher education, along with a loss of control over their own conditions of labor. As Watermeyer and his co-authors (2021, p. 654) observed: 
Marketisation, deregulation and the elevation of competition and productive capacity as the pre-eminent organising principles for higher education have altered the behavioural dynamics and mission focus of universities, ... in pursuit not of public goods but private gains [and] have contributed to the consolidation and legitimisation of undemocratic practices within universities, with which academics paradoxically are, perhaps unwittingly yet no less actively, complicit but also most affected.

What is clear, especially when viewed through the lens of the wider society, is that the pandemic is much more than a medical crisis. At its core is a combination of political, medical, and educational forces marked by the withering of civic culture, the erosion of any sense of shared citizenship, the undermining of the welfare state, and the emergence of a dysfunctional culture of lies, conspiracy theories, and manufactured ignorance (Gellman, 2021). Gellman (2021) argues that former President Donald Trump has convinced many of his followers that the 2020 presidential election was stolen and in doing so has convinced millions to believe in a mass political movement "that is ready to fight by any means necessary, including bloodshed, for its cause." These crises have had far reaching implications for both public and higher education, and the increased surveillance and deskilling of educators. Attacks on critical race theory, the autonomy of educators, and critical thought itself merges with a corporatized model of education in which faculty are reduced to adjunct labor, students are viewed as clients and consumers, and the governing structure of education, especially higher education, is modeled after corporations.

As a number of crises unfold, intellectuals, artists, educators, and other cultural workers are pressured to withdraw into academic specialisms, or they are pressured to look away, and give up their responsibility to use education to address grave social problems such as the threat of nuclear war, ecological devastation, the return of Jim Crow, and the sharp deterioration of democracy. At the level of public education, schools are defunded, teachers are deskilled, and become pawns in a savage war of censorship now waged by Republican Party legislators in a number of states (Giroux, 2021a; see also Giroux, 2021b). Moreover, unions are relentlessly undermined in the ability to work for the rights of teachers and students. Both public and higher education institutions are now subjected to neoliberal modes of governance that view students as consumers, faculty as a pool of casual labor, and knowledge as a commodity. Gone is the age of the academic as a public intellectual whose academic work and public interventions were a model for enriching public life and addressing staggering forms of economic inequality, needless wars, and class and racial injustices. Gone are the diverse teachers and academics who worked tirelessly to inspire individuals and social movements to unleash the energy, insights, and passion necessary to keep alive the spirit, promises, and ideals of a radical democracy. It almost seems quaint to talk about an age when educators, as Lyamlahy (2019) has argued, produced research that focused on "silent questions and neglected connections," developed a language that generated a "more active affinity between people," and engaged in pedagogical practices and cultural work that highlighted a politics that refused "to divorce itself from social institutions and material relations of power and domination."

No longer taking on the role of border crossers, too many academics are reduced to shortterm contracts and temporary work that both undermines academic freedom and reduces them to part-time clerks trying to survive. This is an especially difficult time for educators, many of whom have pushed back against the utter degradation of teaching and learning that has gone on with full force since the 1980s in the United States. Accentuating the assault on education, the pandemic has further weakened education as it has substituted the language of method, instrumental rationality, and technological mastery for substantive questions about the role of education in a time of rising authoritarian nationalism and economic populism.

Educators need a new language, vision, politics, and renewed sense of solidarity. They need

Journal of the Scholarship of Teaching and Learning, Vol. 21, No. 4, December 2021. josotl.indiana.edu 
to bring truth out of shadows and create a space for critical thought and civic action, while pushing at the frontiers of the social imagination. Most of all, they need to acknowledge and fight for the centrality of education in shaping modes of agency, identity, values, social relation, and visions of the future. It may be too much to ask, but how might it be possible for those of us in various pedagogical spaces, sites, and terrains in which knowledge is produced and the future is re-imagined, contribute to inventing a politics that gives meaning to the promises and ideals of a radical democracy. This is especially true at a time when language has been hijacked and used in the service of dehumanization, hatred, and violence. Language is never innocent, and history teaches us that language that begins with hate often ends with violence.

Can we invent a politics and system of education capable of both operating and challenging a society defined by the scourge of market values and the growing registers of instrumental rationality and populist authoritarianism? Morrison (2019, p. 30) was right in observing that the work of teachers, public intellectuals, and other cultural workers "is more indispensable then ever before because the world is more dangerous than ever before." In what follows, I want to explore these pressing issues by examining education, pedagogy, and teaching and learning in the broadest terms and in relation to the multiple sites in which it takes place. That is, I want to raise issues about the centrality of education within a broad and comprehensive understanding of politics itself, particularly at a time when democracy is receding across the globe (Repucci, 2020; Silva-Leander et.al., 2021).

Across the globe, democracy is on the ropes (Csaky, 2021). Such a decline can in part be measured by the fact that democratic institutions such as the independent media, schools, the legal system, certain financial institutions, and higher education are under siege. Education has increasingly become a tool of domination as right-wing pedagogical apparatuses controlled by the entrepreneurs of hate who attack workers, the poor, people of color, refugees, immigrants from the South, and others considered disposable. In the midst of an era when an older social order is crumbling and a new one is struggling to define itself, there emerges a time of confusion, danger, and moments of great restlessness. The present moment is once again at a historical juncture in which the forces of democracy and authoritarianism are vying for shaping a future that appears to be either an unthinkable nightmare or a realizable dream.

The architects of a new breed of authoritarian politics-referred to in the mainstream press illiberal democracy-increasingly dominate major cultural apparatuses and other commanding political and economic institutions across the globe. Their nightmarish reign of misery, violence, and disposability is legitimated, in part, through their control of all sorts of knowledge producing settings that construct a vast machinery of manufactured consent. This reactionary educational formation includes the mainstream broadcast media, digital platforms, the Internet, and print culture, all of which participate in an ongoing spectacle of violence, the aestheticization of politics, the legitimation of opinions over facts, and an embrace of a culture of ignorance.

It is hard to imagine a more urgent moment for taking seriously the call to make education central to politics. The rule of authoritarianism is imposed less and less by military coups than it is through elections subverted by the force of oppressive forms of education that extend from the schools to social media and other cultural apparatuses. The educational force of the cultural sphere is now amplified by the merging of power and new instruments of culture that have produced powerful sites of struggle in an effort to normalize and legitimate dominant ideas, values, and social relations. Making education central to politics means addressing the cultural forces shaping policies and society to create a formative culture in the service of democratic modes of agency, desires, and identities. If education is going to work in the service of democracy, it needs a new vision and language in which the call for real change resonates with the concrete needs, desires, values, and modes of identification that working-class people of every stripe can understand and relate to

Journal of the Scholarship of Teaching and Learning, Vol. 21, No. 4, December 2021. josotl.indiana.edu 
critically.

If we are going to develop a politics capable of awakening our critical, imaginative, and historical sensibilities, it is crucial for educators and others to create a political project infused with a language of critique and possibility, informed by the crucial notion that there is no substantive democracy without informed citizens. Such a language is necessary to enable the conditions to forge a collective international resistance among educators, youth, artists, and other cultural workers in defense of not only public goods, but also a democracy with the guarantee of not only civil and political rights, but also economic rights that ensure both dignity and a meaningful sense of agency (Fountain, 2020). In an age of social isolation, information overflow, a culture of immediacy, consumer glut, and growing right-wing populist movements, it is all the more crucial to take seriously the notion that a democracy cannot exist or be defended without informed and criticallyengaged citizens.

Education must be broadly understood as taking place in various locations and defined, in part, through its interrogation on the claims of democracy. As Dorfman (2020) argues, it is time to create the cultural institutions and pedagogical conditions in multiple sites extending from the mainstream press to the online digital world in order "to unleash the courage, energy, joy and, yes, compassion with which rebellious millions [can] defy fear and keep hope alive in these traumatic times." As Bourdieu and Grass (2020, p. 2). argued, "important forms of domination are not only economic but also intellectual and pedagogical and lie on the side of belief and persuasion [making it all the more] important to recognize that intellectuals bear an enormous responsibility for challenging this form of domination." This is an especially crucial demand at a time when educational and pedagogical force of the culture works through and across multiple places. Schooling is only one site of education, while movies, television, books, magazines, the Internet, social media, and music are incredibly significant forces in shaping world views, modes of agency, and diverse forms of identification.

In a time when truth has become malleable and people are being told that the only obligation of citizenship is to consume, language has become thinner, more individualistic, detached from history, and more self-oriented, all the while undermining viable democratic social spheres as spaces where politics brings people together as collective agents willing to push at the frontiers of the political and moral imagination. Too many people across the globe have forgotten their civic lessons, and in doing so cede the ground of history to the purveyors of lies, militarism, and white supremacy. As educators and intellectuals, it is crucial to remember that there is no genuine democracy without the presence of citizens willing to hold power accountable, engage in forms of moral witnessing, break the continuity of common sense, and challenge the normalization of antidemocratic institutions, policies, ideas, and social relations.

Making education central to politics suggests that as artists, researchers, and academics we ask uncomfortable questions about what Roy (2001, p. 3) calls "our values and traditions, our vision for the future, our responsibilities as citizens, the legitimacy of our 'democratic institutions,' the role of the state, the police, the army, the judiciary, and the intellectual community." Education has the task of creating the conditions in which people develop a collective sense of urgency that prompts a desire to learn how to govern, rather than merely how to be governed. Education for empowerment means creating informed and critically-engaged social movements willing to fight the emotional plagues, economic inequality, human misery, systemic racism, and collapse of the welfare state caused by neoliberal capitalism and other forms of authoritarianism. Democracy's survival depends upon a set of habits, values, ideas, culture, and institutions that can sustain it. Democracy is both precarious and always unfinished, and its fate and future are not only a political issue but an educational one as well.

In the end, there is no democracy without an informed public and no justice without a

Journal of the Scholarship of Teaching and Learning, Vol. 21, No. 4, December 2021. josotl.indiana.edu 
language critical of injustice. Moreover, it is crucial to acknowledge that capitalism and democracy are not the same thing. A more radical notion of democracy emphasizes not only personal and political freedoms but also economic rights. This view of democracy is a crucial project that must inform any radical vision education in the future. Democracy should be a way of thinking about education, one that thrives on connecting pedagogy to the practice of freedom, learning to ethics, and agency to the imperatives of social responsibility and the public good. In the age of nascent fascism, it is not enough to connect education with the defense of reason, informed judgment, and critical agency; it must also be aligned with the power and potential of collective resistance. We live in dangerous times. Consequently, there is an urgent need for more individuals, institutions, and social movements to come together in the belief that the current regimes of tyranny can be resisted, that alternative futures are possible, and that acting on these beliefs through collective resistance will make radical change happen.

Educators need to develop a politics infused with the notion that history is open, and that it is necessary for people to think otherwise to act otherwise, especially if we want to imagine and bring into being alternative democratic futures and horizons of possibility. At stake here is the need to develop a vision infused with a mix of justice, hope, and struggle, a task in the age of pandemics that has never been more important than it is today. Moreover, in the face of the emerging tyranny and fascist politics that are spreading across the globe, it is time to merge a sense of moral outrage with a sense of civic courage and collective action.

Global neoliberal capitalism reproduces pedagogical "death zones of humanity" that undermine the capacity for people to speak, write, and act from a position of empowerment and be responsible to themselves and others. Against this form of depoliticization, there is the need for modes of civic education and critical literacy that provide the bridging work between thinking critically and the possibility of interpretation as intervention. Such bridging work is committed to the realization that there is no resistance without hope, and no hope without a vision of an alternative society rooted in the ideals of justice, equality, and freedom.

Education is central to politics because it provides the foundation for those of us who believe that democracy is a site of struggle, which can only be engaged through an awareness of both its fragility and necessity. As educators what we cannot do is look away, paralyzed by indifference, a deadly pessimism, or a death-dealing cynicism. Education performs a crucial, if not noble, task in society. It is a crucial bulwark of producing students as engaged and critical citizens while constructing a deeper and expansive understanding of democracy. Education in its various forms is always an outgrowth of struggle. Once again, the necessity to struggle over education in a time of tyranny is with us with a deep sense of urgency. This urgency demands that educators develop a new language, vision, and politics to address the current challenges faced by educators and the wider society. Resistance is no longer an option; it is a necessity if democracy is to survive.

\section{References}

Alford, B. \& Kroll, K. (2020, July 12). Post-Pandemic Education Must Move Beyond Mere Job Training. Truthout. https://truthout.org/articles/post-pandemic-education-must-move-beyond-merejob-training/

Blum, S. D. (2020, April 22). Why We're Exhausted by Zoom. Inside Higher Education. https://www.insidehighered.com/advice/2020/04/22/professor-explores-why-zoomclasses-deplete-her-energy-opinion

Bourdieu, P. \& Grass,G. (2002). The 'Progressive' Restoration: A Franco-German Dialogue. New Left Review, (14). 2

Csaky, Z. (2021, December). The Antidemocratic Turn. Freedom House.

Journal of the Scholarship of Teaching and Learning, Vol. 21, No. 4, December 2021. josotl.indiana.edu 
https://freedomhouse.org/report/nations-transit/2021/antidemocratic-turn

Cummings McLean, D. (2020, October 16). Pope Francis Calls for a Global Education Pact with Humanity at its Center. Life Site. (Oct 16, 2020). https://www.lifesitenews.com/news/popefrancis-calls-for-a-global-education-pact-with-humanity-at-its-center

Dorfman, A. (2020, November 11) Defying Fear in Traumatic Times. Counterpunch. https://www.counterpunch.org/2020/11/11/defying-fear-in-traumatic-times/

Fountain, B. (2020, November 19). What Has Minimalist Democracy Gotten Us? The New York Review. https://www.nybooks.com/articles/2020/11/19/election-what-has-minimalistdemocracy-gotten-us/

Gellman, M. (2021, December 6). Trump's Next Coup Has Already Begun. The Atlantic. https://www.theatlantic.com/magazine/archive/2022/01/january-6-insurrection-trumpcoup-2024-election/620843/

Giroux, H. A. (2021a). Jim Crow Politics Have Descended on Education. Truthout. https://truthout.org/articles/politics-have-descended-oneducation/?fbclid=IwAR3tNqsaCm7PbxscA00zHKFlUqYplWddplIHB8eqCa3aNjAve4em EY8UMiQ

Giroux, H. A. (2021b). Race, Politics, and Pandemic Pedagogy: Education in a Time of Crisis. Bloomsbury. https://www.bloomsbury.com/us/race-politics-and-pandemic-pedagogy-9781350184442/

Lyamlahy, K. (2019, December 3). The Professional Stranger: On Abdelkebir Khatibi's 'Plural Maghreb. Los Angeles Review of Books: https://lareviewofbooks.org/article/the-professionalstranger-on-abdelkebir-khatibis-plural-maghreb/

Morrison, T. (2019). The War on Error. The Source of Self-Regard. Knopf.

Repucci, S. (2020) A Leaderless Struggle for Democracy. Freedom House. 3-15. https://freedomhouse.org/sites/default/files/202002/FIW 2020 REPORT BOOKLET Final.pdf

Roy, A. (2001). Power Politics. South End Press. 3.

School Magazine Editorial Action Toronto. (2021, September 2020). Hybrid Learning' is not Learning. https://educationactiontoronto.com/articles/hybrid-learning-is-not-learning/

Silva-Leander, A., Balleste Buxo, E., Fernandez Gibaja, A., Hudson, A., Lara Otaola, M.A., \& Shah, S. (2021). The Global State of Democracy 2021: Building Resilience in a Pandemic Era. International Institute for Democracy and Electoral Assistance. https://www.idea.int/gsod/sites/default/files/2021-11/the-global-state-of-democracy2021 1.pdf

Watermeyer, R., Shankar, K., Crick, T., Knight, C., McGaughey, F., Hardman, J., Ratnadeep Suri, V., Chung, R., \& Phelan, D. (2021). 'Pandemia': a Reckoning of UK Universities' Corporate Response to COVID-19 and its Academic Fallout. British Journal of Sociology of Education. 42(5). 654. https://doi.org/10.1080/01425692.2021.1937058 